\section{ÉLETBIZTOSÍTÁSOK SZIMULÁCIÓS MODELLEZÉSE: AZ LSMC MÓDSZER TÖRLÉSI OPCIÓK ÉRTÉKELÉSÉRE}

Péter Emöke Regina, (NN RAS, junior aktuárius)

A Magyar Aktuárius Társaság 2017-ben Péter Emöke Reginának itélte oda a Biztositásmatematika Ifú Mestere dijat.

\section{ÖSSZEFOGLALÓ}

A különféle életbiztosítási termékekbe ágyazott opciók és garanciák értékének számszerüsítése különösen fontos szerepet kapott a Szolvencia II keretrendszer bevezetésével, illetve a piackonzisztens beágyazott érték módszertanának elterjedésével. Munkámban egy törlési opciók értékelésére alkalmas szimulációs technikát, a least squares Monte-Carlo elnevezésü módszert mutatom be. Lényege, hogy a szóban forgó opció továbbtartási értékére minden időpontban becslést adjon egy speciális regresszió végrehajtása révén.

A módszert az ún. equity-indexed annuity (részvényindexhez kötött járadék) szerződésfajta modellezésén keresztül szemléltetem, melynek lejárati és haláleseti kifizetése egy rögzített index teljesítményétől függ. A kulcskérdés, amelyet igyekeztem körüljárni, az, hogy mennyit tesz hozzá a szerződés értékéhez az a lehetőség, hogy az ügyfél az aktuális visszavásárlási összeg elfogadásával lejárat elött felmondhatja szerződését. Ugyanakkor arra is kerestem a választ, hogy milyen tényezők befolyásolják e törlési opció értékét. Az elemzéseket kétféle modellfeltevés mellett is elvégeztem, amelyek az alaptermékül szolgáló indexárfolyamának dinamikájára vonatkoznak.

Jelen cikk a Budapesti Corvinus Egyetem Biztosítási és pénzügyi matematika mesterszakának aktuárius szakirányán, a 2017. júliusi záróvizsga alkalmával bemutatott szakdolgozat alapján készült.

\section{SUMMARY}

Quantifying the value of options and guarantees embedded in various life insurance products gained especially high importance since the introduction of the Solvency II directive and the methodology of market consistent embedded value. The subject of my work is a simulation technique called least squares Monte Carlo which was successfully adapted for actuarial use as a fast and accurate way of valuing surrender options. The main point of the method is to estimate the continuation value of the option at every time step by performing a specific regression.

I illustrate the method by modelling a so called equity-indexed annuity (EIA) product the maturity and death benefit of which is defined based on the performance of a particular index. The key-question I tried to answer is the extra value generated by the right to accept the actual surrender benefit and terminate the policy before maturity. I was also curious about the effect of different parameters on the option value. I performed the analysis in two different frameworks regarding the dynamics of the underlying index.
This article is based on my thesis written at the actuarial specialization of the Actuarial and financial mathematics MSc of Corvinus University of Budapest and presented with the occasion of the final exam in July 2017.

Kulcsszavak: törlési opció, legkisebb négyzetes Monte-Carlo-módszer, részvényindexhez kötött járadék, rezsimváltó lognormális modell

Keywords: surrender option, least squares Monte Carlo method, equity-indexed annuity, regime switching lognormal model

JEL: G22, C51, E47

DOI: $10.18530 /$ BK.2017.3.52

http://dx.doi.org/1018530/BK.2017.3.52

\section{Bevezetés}

Egészen az 1990-es évek közepéig a biztosítások pénzügyi elemzéséhez szinte kizárólag determinisztikus modelleket használtak. Ezek a statikus paramétereken és feltételezéseken alapuló modellek nem képesek megragadni olyan véletlenszerü fluktuációkat, amelyek akár az ügyfelek viselkedésében, akár a demográfiai vagy éppen makrogazdasági jellemzőkben bármikor jelentkezhetnek. Manapság a legtöbb aktuáriusi kutatásnak és számításnak jelentős részét teszik ki a széles körű szimulációk és a sztochasztikus modellezés. Ezen módszerek pontosabb és realisztikusabb képet tudnak nyúitani az egyes termékekben rejlő kockázatokról, ezáltal segíthetik a biztosítókat a pénzügyi tervezésben és a tőkeallokációs döntésekben.

A beágyazott opciók a biztosító profitjának csökkenéséhez vezethetnek, ha az ügyfelek optimális módon hívják le azokat.

Szakdolgozatomban egy ilyen sztochasztikus szimulációs jellegű módszer biztosítási területen való alkalmazhatóságát szerettem volna bemutatni. Választásom a least squares Monte-Carlo (LSMC) elnevezésű technikára esett, amelyet eredetileg amerikai opciók árazására dolgozott ki Longstaff és Schwartz (Longstaff \& Schwartz, 2001), s amelyet később nagy sikerrel adaptáltak a biztosítási terület kutatói, elsősorban mint a törlési opciók értékelésének gyors és pontos módszerét. Az LSMC módszert egy ún. részvényindexhez kötött járadék (equity-indexed annuity = EIA) életbiztosítási termék modellezésén keresztül mutatom be, amelynek haláleseti és elérési szolgáltatása alapértelmezetten egy részvényindex hozamától függ, de beépített minimumgaranciák révén védelmet nyúit az ügyfél számára abban az esetben, ha az index rosszul teljesít. Emellett lehetővé teszi a biztosított számára, hogy törölje szerződését a lejárat előtt, ez esetben szintén garantált bizonyos visszavásárlási összeg. Ezekre 
a garanciákra és a törlési lehetőségre úgy tekinthetünk, mint opciókra, amelyek értékét feltétlen figyelembe kell venni a szerződés értékelésekor. A beágyazott opciók ugyanis a biztosító profitjának csökkenéséhez vezethetnek, ha az ügyfelek optimális módon hívják le azokat. A lejárat előtt törölt szerződések például likviditási veszteségeket okozhatnak, mivel arra kényszeríthetik a biztosítót, hogy hosszú távú befektetésnek szánt eszközeit idő előtt értékesítse.

A törlési opció árazására nincsen általánosan elfogadott, egységes módszer, ez máig aktív kutatások tárgyát képezi. Az első próbálkozók között voltak, akik zárt formulát próbáltak adni az opcióértékre, mások diszkrét opcióárazási módszerrel, szcenáriófákkal ragadták meg a problémát. Az általam is alkalmazott LSMC módszeren alapulnak például Andreatta és Corradin (2003), Bernard és Lemieux (2008), valamint Kelani és Quittard-Pinon (2013) írásai is. Ezek egyre gazdagabb szempontrendszert figyelembe véve vizsgáliák a törlési opciót is tartalmazó szerződések értékelésének problémáját. Bernard és Lemieux (2008) már figyelembe veszi a mortalitási kockázatot is, Kelani és Quittard-Pinon (2013) pedig változatos modellfeltevésekkel él a szolgáltatások mértékét meghatározó alaptermék alakulását illetően. Ez utóbbi két cikk alapkövét képezte a szakdolgozatnak.

A jelen cikkben is megjelenő equity-linked típusú termékek modellezésének egész könyvet szentel Hardy (2003). Nagy hangsúlyt fektet a haláleseti és lejárati garanciák értékelésére és az általuk képviselt kockázatra, amit nagyban befolyásol a részvényindex alakulása, amelyhez a szolgáltatások értékét kötik. Az index dinamikájának lehetséges modelljeiről is részletesen ír, ami igen hasznos volt számomra. Hardy korábbi cikke (Hardy, 2001) az index modellezésében nyújtott segítséget, hiszen részletesen tárgyalja a rezsimváltó lognormális modell illesztésének és alkalmazhatóságának problémáját hosszú távú részvényhozamok esetén.

A cikk felépítése a továbbiakban a következők szerint alakul. Előbb részletezem a vizsgált szerződés, illetve a törlési opció modellezésének specifikumait, majd az index alakulására vonatkozó kétfajta modellt ismertetem. Ezután az LSMC módszer megvalósításának lépéseit mutatom be. Ezt követi a számítási eredmények bemutatása, végül a következtetések és tanulságok rövid összefoglalása olvasható.

\section{Törlési opciót tartalmazó equity-linked szerződések modellezése}

Az ún. equity-linked szerződésfajtát az életbiztosítási fedezet és a befektetési célok ötvözésének igénye hívta életre, amely az utóbbi években egyre jobban felerősödött, háttérbe szorítva a hagyományos életbiztosítási formákat. Ezek a biztosítások rögzített haláleseti vagy elérési kifizetés helyett a majdani juttatások mértékét egy részvény vagy részvényindex teljesítményéhez kötik. Általában tartalmaznak minimumgaranciákat mind haláleset, mind lejárat esetére (guaranteed minimum death / maturity benefit), illetve lehetővé teszik az ügyfél számára a lejárat előtti törlést esetleges büntetés fejében, amelyhez szintén elöre rögzített garantált kifizetést csatolnak (guaranteed minimum surrender benefit). Ezen minimumgaranciák védelmet nyújtanak a befektetőnek abban az esetben, ha az index, amelynek a hozamát egyébként megígérik számára a szerződésben, rosszul teljesít.

\section{A törlési opció értéke az a felár, amelyet a lejárat előtti lehívhatóság von maga után.}

A modellezés problémáját úgy közelíthetjük meg, ha a fix lejáratú, különböző garanciákat tartalmazó equity-linked szerződésekre úgy tekintünk, mint európai opciók portfóliójára, a beépített törlési opcióra pedig, mint amerikai opcióra. Ekkor a törlési opció értéke az a felár, amelyet a lejárat előtti lehívhatóság von maga után. A törlés modellezése érdekében általában feltételezzük, hogy a törlési mechanizmus dinamikus, és a pénzügyi környezet alakulása befolyásolja. Vagyis úgy tekintjük, hogy az ügyfél racionális, kockázatsemleges döntéshozó, azaz akkor él a törlés lehetőségével, ha a törlési garancia meghaladja a szerződés továbbtartásának piaci értékét az adott időpontban. A valóságban természetesen ez az optimális viselkedésre vonatkozó feltételezés nem állja meg a helyét, hanem az ügyfelek külső tényezőktől vezérelve olyankor is törölnek, amikor az nem vezet a befektetésük végső értékének maximalizálásához. Ezek a modellek tehát a biztosító nézőpontjából a „legrosszabb" esetet ragadják meg, és az eredményül kapott opcióérték csak felső becslése a valódinak.

A következőkben a Bernard és Lemieux (2008) cikkben leírt módszer részleteit mutatom be, amelyet - a dolgozat fö céljaként - meg is valósítottam, helyenként lényeges tartalmi változtatásokat, illetve kiegészítéseket végezve. Az index dinamikáját leíró modellek öszszefoglalásánál föként Kelani és Quittard-Pinon (2013), valamint Hardy (2001) cikkeire támaszkodom.

\section{A szerződés jellemző}

A vizsgált szerződés egy ún. equity-indexed annuity (EIA), azaz részvényindexhez kötött járadék, amely abban áll, hogy az ügyfél befektetése az illető index hozamának megfelelően gyarapodik, amelyet majd az elöre rögzített lejáratkor járadékra válthat. Ilyen vagy ehhez hasonló konstrukciók az Amerikai Egyesült Államokban és az angolszász országokban elterjedtek, a magyar piacon egyáltalán nem. Az NN Biztosító termékei között megtalálható Kronosz nevű biztosítás hasonló jellemzőkkel rendelkezik, mint az, amely itt elemzésre kerül, de nem teljesen egyezik meg vele. ${ }^{1}$ Az EIA szerződések kikötnek egy ún. részvételi szintet (participation level / rate), amely korlátozza, hogy az index hozamának mekkora része gyarapítja tulajdonképpen a szerződő megtakarítását. A választott részvételi szint és a garantált minimális szolgáltatási összegeket meghatározó kamatlábak fordítottan arányosak. Megjegyzendő, hogy jelen modell szempontjából lényegtelen a szerződés járadék volta, alakulása csak a lejáratig érdekes. 
Legyen a lejárat ideje az indulástól számítva $T$ év, az ügyfél kezdeti befizetését pedig jelöljük $P$-vel. Feltételezzük, hogy nincs további befizetés. Jelöljük a befektetés hozamának alapjául szolgáló index értékét $S_{t}$-vel a $t$. időpontban, $t=0, \ldots, T$. Feltesszük továbbá, hogy a biztosítás a P egyszeri díj a százalékát ígéri majdani juttatásként, kamatoztatva a $g$ garantált minimum éves kamatláb, illetve az index tartam alatt elért hozama közül a nagyobbikkal. Jelöljük a részvételi szintet leíró paramétert $k$-val, $0<k \leq 1$. A bevezetett jelölésekkel a lejárati kifizetés értéke a következő alakot ölti:

$$
V_{T}=\alpha P \max \left(e^{g T},\left(\frac{S_{T}}{S_{0}}\right)^{k}\right) .
$$

A szerződésről feltesszük azt is, hogy a fenti lejárati kifizetés mellett a biztosított halála esetén is térít bizonyos összeget az adott év végén. Ennek szerkezete a lejárati kifizetésével azonos, a biztosító azonban alkalmazhat eltérő garantált minimum kamatlábat és részvételi

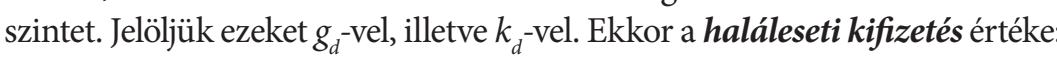

$$
D_{t}=\alpha P \max \left(e^{g_{d} T},\left(\frac{S_{T}}{S_{0}}\right)^{k_{d}}\right), \quad t=1, \ldots, T .
$$

Az egyszerűség kedvéért feltesszük, hogy a törlés tetszőleges időpont helyett csakévfordulón tehető meg. Az ügyfél ebben az esetben is hozzájut a befektetéséhez, de az - főként a tartam első éveiben - csonkítva van elöre rögzített büntetőfaktoroknak megfelelően. Jelölje $h$ a törlés esetén garantált éves kamatlábat, $\beta t$ pedig a $t$. évhez tartozó büntetőfaktort, amely általában csökken azévek előrehaladtával. A gyakorlatban a visszavásárlási összeg legtöbbször független az index hozamától; itt is ezzel a feltételezéssel élünk. Tehát, ha az ügyfél a $t$. év végén töröl, akkor az alábbi összeget kapja:

$$
L_{t}=\left(1-\beta_{t}\right) \alpha P e^{h t}, \quad t=1, \ldots, T .
$$

A szerződés tehát három, egymást kizáró esemény hatására szűnhet meg, amelyek mindegyikéhez előre rögzített, jól meghatározott kifizetés tartozik.

A törlési opció értékének meghatározása tulajdonképpen visszavezethető az optimális megállási időpont meghatározására. Az optimális stratégia abból áll, hogy a lejárat előtti időpontokban az ügyfél összehasonlítja az azonnali visszavásárlási értéket a szerződés folytatásából adódó cash-flow-k várható jelenértékével, és töröl, ha az utóbbi kevésbé értékes. Vagyis az ügyfél abban az esetben fog tisztán pénzügyi megfontolásból törölni egy adott $t$ időpontban, ha $L_{t}>C_{t}$, ahol $C_{t}$ a szerződés $t$-beli továbbtartási (piaci) értékét jelöli. A valóságban sok esetben az ügyfeleknek jóval összetettebb indokaik vannak, amikor a törlés mellett döntenek. Ezért a szerzők bevezetnek egy paramétert - legyen ez $\lambda \geq 1$-, amely azt hivatott árnyalni, hogy minden ügyfél számára más-más döntés lehet optimális. Egy adott $\lambda$ paraméterrel rendelkező biztosított visszavásárlásának feltétele tehát a $t$. év végén: $L_{t}>\lambda C_{t}$

\section{A törlési opció értékének meghatározása visszavezethető az op-} timális megállási időpont meghatározására.

Az egyszerüség kedvéért Bernard és Lemieux teljes és tökéletesen likvid piacot feltételeznek, és eltekintenek minden költségtől. Én is ezt követem. A piac teljessége miatt létezik a $Q$ egyértelmü, kockázatsemleges mérték, amely alatt a csak lejárati kifizetést tartalmazó, és ezért európai típusúnak nevezhető szerződés igazságos értékét a tartam kezdetén a jövőbeli cash-flow-k várható jelenértéke adja:

$$
\xi\left(S_{0}, g, k, T\right)=e^{-r T} \mathbb{E}_{Q}\left(V_{T}\right)
$$

ahol $r$ a konstansnak feltételezett kockázatmentes kamatláb.

Tekintsük most azt a szerződést, amely haláleseti kifizetéseket is tartalmaz, de törlési opciót még nem. Jelölje ennek a kezdeti igazságos értékét $V_{0}^{E}$. Figyelembe véve a mortalitási kockázatot, ezt a következö formulával fejezhetjük ki:

$$
V_{0}^{E}={ }_{T} p_{x} \cdot \xi\left(S_{0}, g, k, T\right)+\sum_{t=0}^{T-1}{ }_{t} p_{x} q_{x+t} \cdot \xi\left(S_{0}, g_{d}, k_{d}, t+1\right),
$$

ahol

- $\quad \xi\left(S_{0^{\prime}} g_{d,} k_{d} t+1\right)$ a különböző évekhez tartozó haláleseti kifizetések kockázatsemleges várható értéke, diszkontálva a kezdeti időpontra,

- $\quad q_{x+t}$ annak a valószínüsége, hogy egy év elején $x+t$ éves egyén meghal az illető év vége előtt,

- $\quad p_{x+t}=1-q_{x+t}$ annak a valószínűsége, hogy egy $x+t$ éves egyén túléli az adott évet,

- $\quad{ }_{T} p_{x}=\Pi(j=0)^{\wedge}(t-1) p_{x+j}$ annak a valószínüsége, hogy egy $x$ éves egyén túlél legalább $t$ évet.

Mielőtt rátérnénk a kulcskérdésre, vagyis arra, hogyan lehet a törlési opció értékét is figyelembe venni, ismertetem azon sztochasztikus modelleket, amelyeket kipróbáltam az alaptermékül szolgáló index alakulásának szimulálásához, illetve bemutatom a $\xi(S, g, k, T)$ mennyiség kiszámításának módját a különböző modellkeretekben, ami központi szerepet játszik majd az opcióérték meghatározásában. 


\section{Az index dinamikájának modellezése és következményei}

\section{Black-Scholes keretrendszer}

Az alapterméket képező index dinamikájának modellezéséhez legegyszerűbb a Black-Scholes keretrendszert választani. Eszerint az index árfolyamának alakulását a

$$
d S_{t}=r S_{t} d t+\sigma S_{t} d W_{t}
$$

sztochasztikus differenciálegyenlet írja le, azaz egy geometriai Brown-mozgás (Geometric Brownian Motion - GBM). $\sigma$ az index volatilitása, $W_{t}$ pedig a $Q$ mérték szerinti Wiener-folyamat. Ismeretes, hogy ebben a klasszikus esetben az index árfolyamának $t$-beli értéke zárt alakban is kifejezhető az Ito-formula segítségével: $s_{t}=s_{0} e^{\left(r-\frac{\sigma^{2}}{2}\right) t+\sigma w_{t}}$. Ezt az összefüggést és a várható érték definícióját alkalmazva levezettem a $\xi\left(S_{0, g} g, k, T\right)$ értékét, amelyre az alábbi kifejezés adódik:

$$
\xi\left(S_{0}, g, k, T\right)=\alpha P\left[e^{(g-r) T} \Phi(\gamma)+e^{(k-1)\left(r+k \frac{\sigma^{2}}{2}\right) T} \Phi(-\gamma+k \sigma \sqrt{T})\right]
$$

ahol $\Phi(\cdot)$ a standard normális eloszlás eloszlásfüggvénye, és $\gamma=\frac{g-k\left(r-\frac{\sigma^{2}}{2}\right)}{\sigma k} \sqrt{T}$.

Értelemszerűen ugyanígy számolható a haláleseti szolgáltatás diszkontált várható értéke $-\xi\left(S_{0}, g_{d}, k_{d}, t+1\right)$ - is a különböző $t$ értékek esetén a megfelelő $g_{d}$ és $k_{d}$ behelyettesítésével.

\section{Rezsimváltó lognormális modell}

Az előző modell egyik legtöbbet emlegetett kritikája, hogy nem képes megragadni a volatilitás paraméter sztochasztikus változékonyságát. Ennek beépítésére egyszerű megközelítés a rezsimváltó lognormális modell (regime switching lognormal - RSLN). Jelöljük $Y$-vel az index loghozamát a $[t, t+1), t=0, \ldots, T-1$ részperiódus esetén. Azt tesszük fel, hogy $Y$ két különböző állapotban - ún. rezsimben - lehet, amelyek között véletlenszerűen váltakozik. Az állapotfolyamat dinamikáját egy Markov-folyamat határozza meg, vagyis az állapotok közötti váltás valószínűsége csak az aktuális rezsimtől függ. A [t,t+1) részintervallumra vonatkozó állapotot jelölje $\zeta_{\text {, }}$ amely tehát az 1 és 2 értékeket veheti fel. Az $S_{t}$ árfolyamatról feltesszük, hogy a $\zeta$ állapotra feltételesen geometriai Brown-mozgást követ, amiből pedig következik, hogy a loghozam bármely diszkrét időintervallum esetén normális eloszlású. Tehát

$$
Y_{t}=\ln \frac{s_{t+1}}{s_{t}} \mid \zeta_{t} \sim N\left(\mu_{\zeta_{t}}, \sigma_{\zeta_{t}}^{2}\right), \quad t=0, \ldots, T-1,
$$

vagyis a két különböző állapotban a loghozamot más-más várható érték és szórás paraméter jellemzi. Ez sokkal inkább megfelel a valóságnak, mint a konstans volatilitás feltevése, hiszen a pénzügyi piacok esetén ténylegesen megfigyelhetö, hogy időnként hajlamosak kimozdulni a stabilnak mondható, alacsonyabb volatilitású állapotból, és egy magas volatilitással jellemezhetö, instabil rezsimre váltani. Ilyen időszakok bekövetkezését okozhatja például a politikai vagy gazdasági helyzet rövidebb távú bizonytalansága. Az átmenetmátrix, amely a két állapot közötti véletlen váltások valószínűségét foglalja össze:

$$
P=\left(\begin{array}{ll}
p_{1,1} & p_{1,2} \\
p_{2,1} & p_{2,2}
\end{array}\right),
$$

ahol $p_{i, j}=P\left(\zeta_{t+1}=j \mid \zeta_{t}=i\right)$ annak a valószínüsége, hogy a $t$. időpontban $i$ állapotban levő folyamat $j$ rezsimre vált a $t+1$. időpontban, $(i, j) \in\{1,2\} \times\{1,2\}$. Értelemszerűen $\sum_{j=1}^{2} p_{i, j}=1, i \in\{1,2\}$. A felírt kétállapotú lognormális modellhez tehát hat paramétert kell megbecsülni: $\theta=\left\{\mu_{1}, \mu_{2} \sigma_{1,} \sigma_{2,} p_{1,2} p_{2,1}\right\}$. A paraméterbecslés maximum-likelihood elven végezhetö el, amelyet alább részletezek.

Tegyük fel, hogy a tekintett részperiódusok most hónapok, és legyen $C_{t} \mathrm{a}[t, n)$ időintervallum alatt az 1-es állapotban eltöltött összes hónap száma, ahol $n$ a teljes időszak hónapokban kifejezett hossza. $C_{t}$ így egy diszkrét valószínűségi változó, amely a $c \in\{0,1, \ldots, n-t\}$ értékeket veheti fel. Feltételes valószínűség-eloszlását, ahol a feltétel az eggyel korábbi, $[t-1, t)$ időszakban érvényes állapot, meg lehet határozni egy rekurzív képlet segítségével, amennyiben ismerjük a fenti átmenetvalószínűségeket:

$$
\begin{array}{r}
P\left(C_{t}=c \mid \zeta_{t-1}\right) \\
\quad= \begin{cases}P\left(C_{t+1}=c \mid \zeta_{t}=2\right) p_{\zeta_{t-1,2}}+P\left(C_{t+1}=c-1 \mid \zeta_{t}=1\right) p_{\zeta_{t-1,1},} & \text { ha } c \in[0, n-t] \\
0, & \text { különben } .\end{cases}
\end{array}
$$

Észrevehető, hogy az utolsó részintervallum, vagyis $t=n-1$ esetén a következő összefüggések érvényesek:

$$
\begin{array}{ll}
P\left(C_{n-1}=1 \mid \zeta_{n-2}=1\right)=p_{1,1,} & P\left(C_{n-1}=0 \mid \zeta_{n-2}=1\right)=p_{1,2,} \\
P\left(C_{n-1}=1 \mid \zeta_{n-2}=2\right)=p & P\left(C_{n-1}=0 \mid \zeta_{n-2}=2\right)=p
\end{array}
$$

Ezt az észrevételt és a fenti rekurziót használva meghatározható a kezdeti időpontban érvényes eloszlás arra feltételesen, hogy melyik rezsimből indul a folyamat: $P\left(C_{0}=c \mid \zeta_{-}=1\right)$ illetve $P\left(C_{0}=c \mid \zeta_{-1}=2\right)$. Ebből pedig $C_{0}$ eloszlása:

$$
\left.P\left(C_{0}=c\right)=: p(c)=\pi_{1} P\left(C_{0}=c / \zeta_{1}=1\right)+\pi_{2} P\left(C_{0}=c / \zeta_{1}^{-}\right)=2\right),
$$

ahol $\pi_{1}$ és $\pi_{2}$ a két állapot feltétel nélküli valószínüsége. Ezeket az értékeket az invariáns eloszlást kifejező $\bar{\pi} P=\bar{\pi}$ egyenlet megoldása adja (lásd Hardy, 2001)

$$
\pi_{1}=\frac{p_{2,1}}{p_{1,2}+p_{2,1}}, \quad \pi_{2}=\frac{p_{1,2}}{p_{1,2}+p_{2,1}}
$$


$C_{0}$ tulajdonképpen a teljes tartam alatt az 1-es állapotban összesen eltöltött hónapok számát fejezi ki, jelöljük ezt a továbbiakban $C$-vel. Ennek eloszlását ismerve a lejáratkori $S_{n}$ árfolyam feltételes eloszlása azonnal adódik:

$$
\begin{gathered}
S_{n} / C \sim \operatorname{lognorm}\left(\ln S_{0}+\mu^{*}(C), \sigma^{*}(C)\right), \text { ahol } \\
\mu^{*}(C)=C \mu_{1}+(n-C) \mu 2, \\
\sigma^{*}(C)=\sqrt{\left(C \sigma_{1}^{2}+(n-C) \sigma_{2}^{2}\right) .}
\end{gathered}
$$

Ezt ismerve a (3) képlettel adott várható érték kifejezhető a teljes valószínűség tételének segítségével:

$$
\begin{aligned}
& \xi\left(S_{0}, g, k, T\right)=\mathbb{E}_{C}\left[e^{-r T} \mathbb{E}_{Q}\left[\alpha P \max \left(e^{g T},\left(\frac{S_{T}}{S_{0}}\right)^{k}\right) \mid C\right]\right] \\
& =\alpha P \sum_{c=0}^{T}\left[e^{(g-r) T} \Phi(\gamma(c))+e^{(k-1)\left(r+k \frac{\left(\sigma^{*}(c)\right)^{2}}{2}\right)} \Phi\left(-\gamma(c)+k \sigma^{*}(c)\right)\right] p(c),
\end{aligned}
$$

ahol $\gamma(c)=\frac{g T-k\left(r T-\frac{\left(\sigma^{*}(c)\right)^{2}}{2}\right)}{\sigma^{*}(c) k}$. Tehát csak aktualizálni kell az eredeti formulában szereplö $\sigma$-tól függő tényezőket $c$ függvényében.

\section{A modell paramétereinek maximum-likelihood becslése}

Jelölje továbbra is $Y_{t}=\ln \frac{S_{t+1}}{s_{t}}$ a $t+1$ havi loghozamot. Az $y=\left(y_{1}, y_{2}, \ldots, y_{n}\right)$ megfigyelt minta log-likelihood függvénye:

$$
I(\theta)=\sum_{t=1}^{n} \ln f\left(y_{t} \mid y_{t-1}, y_{t-2, \cdots, y_{1, \theta}}\right)
$$

Ennek kiszámítása rekurzió segítségével lehetséges:

$$
\begin{gathered}
f\left(\zeta_{t}, \zeta_{t-1}, y_{t} \mid y_{t-1}, y_{t-2}, \ldots, y_{1}, \theta\right)=p\left(\zeta_{t-1} \mid y_{t-1}, y_{t-2}, \ldots, y_{1}, \theta\right) \times p\left(\zeta_{t} \mid \zeta_{t-1}, \theta\right) \times f\left(y_{t} \mid \zeta_{t}, \theta\right), \quad \forall t \\
\quad \begin{array}{c}
f\left(\zeta_{t}, \zeta_{t-1}, y_{t} \mid y_{t-1}, y_{t-2}, \ldots, y_{1}, \theta\right) \\
=p\left(\zeta_{t-1} \mid y_{t-1}, y_{t-2}, \ldots, y_{1}, \theta\right) \times p\left(\zeta_{t} \mid \zeta_{t-1}, \theta\right) \times f\left(y_{t} \mid \zeta_{t}, \theta\right), \quad \forall t
\end{array}
\end{gathered}
$$$$
\text { ahol }
$$

\section{- $\quad p\left(\zeta_{t} \mid \zeta_{t, p} \theta\right)$ az állapotok közötti átmenet valószínűsége,}

- $\quad f\left(y_{t} \mid \zeta_{t} \theta\right)$ a $\mu_{\zeta_{t}}$ és $\sigma_{\tau_{t}}$ paraméterekkel rendelkező normális eloszlás sürüségfüggvénye az $y_{t}$ helyen, azaz $\frac{1}{\sigma_{\zeta_{t}}} \phi\left(\frac{y_{t}-\mu_{\zeta_{t}}}{\sigma_{\zeta_{t}}}\right)$ ahol $\phi(\cdot)$ a standard normális eloszlás sürüségfüggvénye,
- $p\left(\zeta_{t-1} \mid y_{t-1} y_{t-2}, \ldots, y_{P} \theta\right)$ pedig az előbbi rekurzió alapján számolható feltételes állapot-valószínüség:

$$
\begin{aligned}
& p\left(\zeta_{t-1} \mid y_{t-1}, y_{t-2}, \ldots, y_{1}, \theta\right) \\
& =\frac{f\left(\zeta_{t-1}, \zeta_{t-2}=1, y_{t-1} \mid y_{t-2}, y_{t-3}, \ldots, y_{1}, \theta\right)+f\left(\zeta_{t-1}, \zeta_{t-2}=2, y_{t-1} \mid y_{t-2}, y_{t-3}, \ldots, y_{1}, \theta\right)}{f\left(y_{t-1} \mid y_{t-2}, y_{t-3}, \ldots, y_{1}, \theta\right)} .
\end{aligned}
$$

$\operatorname{Az} f\left(y_{t} \mid y_{t-1}, y_{t-2}, \ldots, y_{1}, \theta\right)$ mennyiséget a (4) egyenlet négy lehetséges értékének összegzésével kapjuk, amelyek a $\zeta_{t} \in\{1,2\}$ és $\zeta_{t-1} \in\{1,2\}$ kombinálásából származnak.

A rekurzió elindításához szükség van az induló állapot valószínűségére, $p\left(\zeta_{0}\right)$-ra, amelyet a már említett $\pi$ és $\pi$ feltétel nélküli valószínűségekre állíthatunk be. Így az invariáns eloszlás tulajdonságát kihasználva adott $\theta$ mellett az alábbi értékekből indíthatjuk a rekurziót:

$$
\begin{aligned}
& f\left(\zeta_{1}=1, y_{1} \mid \theta\right)=\pi_{1} \frac{1}{\sigma_{1}} \phi\left(\frac{y_{1}-\mu_{1}}{\sigma_{1}}\right), \\
& f\left(\zeta_{1}=2, y_{1} \mid \theta\right)=\pi_{2} \frac{1}{\sigma_{2}} \phi\left(\frac{y_{1}-\mu_{2}}{\sigma_{2}}\right), \\
& f\left(y_{1} \mid \theta\right)=f\left(\zeta_{1}=1, y_{1} \mid \theta\right)+f\left(\zeta_{1}=2, y_{1} \mid \theta\right) .
\end{aligned}
$$

A paraméterbecslést elvégeztem saját adatokon, ezt a számítási eredmények közlése során mutatom be.

\section{Legkisebb négyzetes Monte-Carlo-módszer a törlési opció értékelésére}

Amint a neve is mutatja, két elven alapszik az értékelési folyamat: a legkisebb négyzetek módszerével történő regressziós becslésen és a Monte-Carlo szimulációs technikán. A Monte-Carlo-jelleg abban érhető tetten, hogy az alaptermék alakulásának $n$ darab trajektóriája mentén megbecsüljük az optimális törlési időpontot, majd ezek alapján kiszámoljuk a szerződés kezdeti igazságos értékét minden trajektória esetén, és ezeket átlagoljuk. A kapott értékből kivonva a sima, európai jellegű szerződés értékét, amelyet $V^{E}{ }_{0}$-vel jelöltünk, megkapjuk a törlési opció értékét is. A legisebb négyzetek módszerét azon a ponton használjuk fel, amikor a szerződés továbbtartási értékét kell megbecsülni annak érdekében, hogy az azonnali visszavásárlási értékkel összehasonlítva meg tudjuk határozni az ügyfél döntését az adott időpontban. Ez a továbbtartási érték az arbitrázsmentesség feltevése mellett úgy fejezhető ki, mint a jövőbeli potenciális juttatásoknak az adott értékelési időpontra diszkontált várható értéke, feltételezve az alaptermékről aktuálisan rendelkezésre álló információ ismeretét. A módszer kulcslépése az az észrevétel, hogy ez a feltételes várható érték bizonyos technikai feltételek mellett az $L^{2}$ tér része (amely Hilbert-tér, és így van megszámlálható ortonormált bázisa), ezért kifejezhető az 
ő bázisfüggvényeinek lineáris kombinációjaként. Mivel a gyakorlatban csak csonkított bázissal tudunk dolgozni, nyilván csak egy közelítését kapjuk a feltételes várható értéknek. Ezen lineáris kombináció együtthatóinak becslése úgy történik, hogy a továbbtartásból származó, ex-post megvalósult, diszkontált kifizetéseket függő változónak tekintjük egy regressziós modellben, magyarázó változóként pedig a választott bázisfüggvényeket használjuk kiértékelve az index aktuális árfolyamában. Látható tehát, hogy végül csak keresztmetszeti információt használunk fel a becsléshez. Miután a legkisebb négyzetek módszerével meghatározzuk a regressziós együtthatókat, már ki tudjuk számolni a becsült feltételes várható érték függvényt, vagyis a becsült továbbtartási értéket trajektóriánként. Az alábbiakban a megvalósítás részletei következnek.

Összesen $n$ darab trajektóriát használunk: $S^{i}, t=0, \ldots, T, i=1, \ldots, n$ az index árfolyama a $t$. időpontban az $i$. szcenárió esetén. Jelöljük $t_{i}^{*}$-vel az optimális törlési időpontot az $i$. trajektória mentén. Ennek meghatározása hátulról előre haladva történik a Tlejárattól a kezdeti időpontig. Az ügyfél minden lépésben összehasonlítja az azonnali visszavásárlási értékét a továbbtartási értékkel, és ennek függvényében hozza meg optimális döntését az adott időpontban. Kelani és Quittard-Pinon (2013) megjegyzik, hogy az algoritmus ezen része Bellman optimalitási elvén alapszik, amely leegyszerüsítve azt mondja ki, hogy „egy optimális döntési sorozat bármely összefüggő részsorozata is optimális a részsorozatot megelöző döntések által kialakított helyzetben”ii .

A $t=T-1, \ldots, 1$ időpontokban a továbbtartás elméleti értékét jelölje $C_{t}^{\prime}$, melynek meghatározásánál figyelembe kell venni a mortalitási kockázatot, vagyis az ügyfél azon szempontját, hogy meghalhat a következő évben, és ebben az esetben megkapja a $D_{t+1}$ összeget. A $C_{t}^{\prime}$ összeget tehát két részre bonthatjuk:

$$
C_{t}^{\prime}=q_{x+t} e^{-r} E_{Q}\left[V_{t+1} \mid S_{t} \text { halál }\right]+p_{x+t} e^{-r} E_{Q}\left[V_{t+1} \mid S_{t} \text { túlélés }\right] \text {, }
$$

ahol $V_{t}$ a szerződés piaci értéke a $t$. időpontban. Mivel halál esetén tudjuk a jövőbeli kifizetés várható értékét, ezért a képlet átírható:

$$
C_{t}^{\prime}=q_{x+t} e^{-r} E_{Q}\left[D_{t+1} \mid S_{t}\right]+p_{x+t} e^{-r} E_{Q}\left[V_{t+1} \mid S_{t} \text { túlélés }\right]=q_{x+t} \xi\left(S_{p} g_{d} k_{d}, 1\right)+p_{x+t} C_{p}
$$

ahol $C_{t}$ a továbbtartási érték túlélés esetén. Ennek a feltételes várható értéknek a közelítése történik a fent leírt eljárással trajektóriánként. Legyen $B_{l}(\cdot), l=0, \ldots, M$ véges számú bázisfüggvény $L^{2}$-ből. (A megvalósításhoz az első négy Laguerre-polinomot használtam.) Ekkor

$$
\hat{C}_{t}^{i}=\sum_{l=0}^{M} \hat{\beta}_{l} B_{l}\left(S_{t}^{i}\right)
$$

ahol a $\hat{\beta_{l}}$ együtthatókat az alábbi becslésből kapjuk:

$$
\left(\hat{\beta_{0}}, \ldots, \hat{\beta_{M}}\right)^{T}=\left(B^{T} B\right)^{-1} B^{T}\left(y_{1}, \ldots, y_{n}\right)^{T} .
$$

Ebben a képletben $y_{i}=e^{-r} V_{t+1}^{i}$ B pedig egy $n \times(M+1)$-es mátrix, amelynek (i,l)-edik eleme: $B_{.}=B_{l}\left(S_{t}^{i}\right), i=1, \ldots, n, l=0, \ldots, M$. Ha most $\widetilde{C}_{t}^{i}$ jelöli a teljes becsült továbbtartási értéket a $t$. időpontban az $i$. trajektórián, akkor (5) alapján:

$$
\widetilde{C}_{t}^{i}=q_{x+t} \xi\left(S_{t}^{i}, g_{d} k_{d} 1\right)+p_{x+t} \hat{C}_{t}^{i}
$$

Miután az optimális törlési időpont meghatározása megtörtént minden $i$-re, meg tudjuk határozni a szerződés értékének becslését az indulás pillanatában, mégpedig úgy, hogy átlagoljuk az egyes trajektóriák mentén kapott kezdeti értékeket:

$$
\widehat{V}_{0}=\frac{1}{n} \sum_{i=1}^{n} A^{i}
$$

ahol

$$
A^{i}=t_{i}^{*} p_{x} e^{-r t_{i}^{i}} L_{t_{i}^{*}}^{i}+\sum_{t=0}^{t_{i}^{*}-1} p_{x} q_{x+t} e^{-r(t+1)} D_{t+1}^{i} .
$$

Az utóbbi képlet magyarázata az, hogy ha a kezdetben $x$ éves ügyfél valóban megéri a számára optimális törlési időpontot, akkor megkapja az ahhoz tartozó visszavásárlási összeget, viszont ha meghal bármely azt megelőző évben, akkor az illető évhez tartozó haláleseti kifizetés jár a kedvezményezettnek az év végén.

Mindezek alapján az algoritmus, amely megadja a szerződés kezdeti igazságos értékének becslését, a következő lépésekből áll:

1. Generáljuk az index tartam alatti alakulásának $n$ darab trajektóriááát.

2. Minden $i$ trajektória mentén

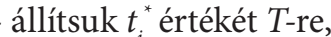

a szerződés értékét pedig $V_{T}{ }^{i}$-re a (1) képletnek megfelelően, - ugyanakkor legyen $L_{T}{ }^{i}=V_{T}^{i}$

3. Minden időpont esetén $t=T$-1-töl $t=1$-ig

- legyen $q$ a megfelelö $q_{x+t}$ és $p=1-q$,

- számítsuk ki a $\hat{\beta}_{0}, \ldots, \hat{\beta}_{M}$ együtthatókat,

majd minden $i$ trajektória mentén aktualizáljuk a szerződés $V_{t}^{i}$ piaci értékét és $t_{i}^{*}$-ot a következők szerint.

${ }^{\star} \mathrm{Ha} L_{t}^{i}>\lambda \widetilde{C}_{t}^{i}$, azaz megéri törölni, akkor legyen $t_{i}^{*}=t$, a szerződés értéke pedig a visszavásárlási értékkel egyezzen meg: $V_{t}^{i}=L_{t}^{i}$.

${ }^{*} \mathrm{Ha} L^{i}<\lambda \widetilde{C}^{i}$, azaz az ügyfél számára nem előnyös a törlés, akkor diszkontáljuk az egy időszakkal későbbi piaci értéket (amit az előző lépésből már ismerünk), és vegyük figye- 
lembe az esetleges elhalálozást: $V_{t}^{i}=q_{x+t} \xi\left(S_{t}^{i}, g_{d} k_{d} 1\right)+p_{x+t} e^{-r} V_{t+1}^{i}$

4. Minden $i$ trajektóriára számítsuk ki az $A^{i}$ értéket a (7) képletnek megfelelően.

5. Végül átlagoljuk ezeket, hogy megkapjuk $\hat{V}_{0}^{- \text {t. }}$

Mivel Monte-Carlo szimulációs technikáról van szó, a fenti (6) becslőfüggvény azonnal javítható, ha kontrollváltozóként használjuk az európai típusú szerződés értékét (amely a mortalitást már tartalmazza), hiszen ennek explicit alakját is ismerjük (lásd (2)), és becslését is ki tudjuk számolni. A becslőképlet ugyanolyan alakú, mint (6), csak az $A^{i}$ értékek képletében az optimális törlési időpontokhoz tartozó visszavásárlási értékek helyett a lejárati értéket kell tekintenünk a megfelelő trajektórián. Vagyis

ahol

$$
\hat{V}_{0}^{E}=\frac{1}{n} \sum_{i=1}^{n} E^{i}
$$

$$
E^{i}{ }_{T} p_{x} e^{-r T} V_{T}^{i}+\sum_{t=0}^{T-1}{ }_{t} p_{x} q_{x+t} e^{-r(t+1)} D_{t+1}^{i} .
$$

A kontrollváltozós becslőképlet:

$$
\nabla_{0}^{k v}=\bar{V}_{0}+\hat{\rho}\left(V_{0}^{E}-\widehat{V}_{0}^{E}\right)
$$

ahol $\hat{\rho}$ a $\frac{\operatorname{cov}\left(A^{i}, E^{i}\right)}{D^{2}\left(E^{i}\right)}$ mennyiség becslése, hiszen ez utóbbi minimalizálja $\hat{V}_{0}^{k v}$ szórásnégyzetét.

A törlési opció értékének becslése előáll az amerikai és az európai típusú szerződések kezdeti igazságos értékének különbségeként:

$$
\hat{O} p_{0}=\hat{V}_{0}^{k v}-V_{0}^{E} \text {. }
$$

\section{A longevity kockázat beépítése az algoritmusba}

A fent leírt algoritmust valósították meg Bernard és Lemieux, valamint jómagam is a szakdolgozatomhoz. A szerzőpáros cikke abban hozott újdonságot, hogy figyelembe vették a mortalitást is a számításaikban, hiszen a korábbi cikkek, amelyek Longstaff és Schwartz módszerét használjákéletbiztosítások értékelésére, még eltekintenek ettől. Szeretném kiemelni, hogy továbblépve a mortalitási kockázat beépítésén, én a longevity kockázatot is figyelembe veszem. A szerzők ugyanis a $q_{x+t}$ értékek meghatározására a nagyon egyszerü, három paraméterrel leírható, Makeham-féle túlélésfügvényt használják, az AEÁ halandósági adataira kalibrált paraméterekkel. Ehhez képest én a Lee-Carter modell segítségével nyert halálozási valószínűségekkel dolgozom. A népszerű halandóság-elörejelző módszert, amely a központi mortalitási rátákra mint függő változókra felírt log-bilineáris, paraméteres egyenleten alapszik, magyar halandósági adatokra alkalmaztam. (A szakdolgozatnak részét képezi a szükséges módszertannak, illetve a megvalósítás részleteinek és eredményeinek leírása is.)

\section{Számítási eredmények bemutatása}

A leírt algoritmust $R$ nyelven implementáltam. Az eredményeket egyenként 10000 trajektória alapján számoltam ki, és ezt egy szimuláción belül $K=25$-ször ismételtem meg, tehát összesen 250000 szcenárió futtatása megy végbe. A módszer gyorsaságáról tanúskodik, hogy a futási idő egy esetben sem haladta meg a 4,8 percet. A $K$-szoros ismétlésből kifolyólag például $K$ darab különböző $\hat{V}_{0}$ becsült értéket kapunk (ez érvényes a többi eredményre is), és így konfidenciaintervallumot is tudunk számolni az illető becsléshez, melynek félhossza:

$$
z_{1-\alpha} \frac{\sigma}{\sqrt{K}}=1,96 \sqrt{\frac{1}{K(K-1)} \sum_{k=1}^{K}\left(\hat{V}_{0}^{k}-\bar{V}_{0}\right)^{2}}
$$

$$
1-\alpha=95 \% \text {, és } \bar{V}_{0}=\frac{1}{K} \sum_{k=1}^{K} \hat{V}_{0}^{k} \text {. }
$$

\section{GBM modell feltevése melletti eredmények}

A következőkben összefoglalom a különböző paraméterbeállításokkal kapott, a GBM modell feltevésén alapuló futtatások eredményeit. A táblázatokban minden esetben feltüntetem az alábbi eredményeket:

- $\quad \hat{V}_{0}$ - törlési opciót tartalmazó szerződés kezdeti igazságos értékének becslése,

- $\quad \hat{V}_{0}^{k v}$ - törlési opciót tartalmazó szerződés kezdeti igazságos értékének kontrollváltozós becslése,

- $V^{E}$ - törlési opció nélküli szerződés elméleti kezdeti igazságos értéke,

- $\hat{O}_{p 0}$ - törlési opció induláskori igazságos értékének becslése,

- \% - hogyan viszonyul az opció értéke az opció nélküli szerződés értékéhez (\%-os arány),

- konf. int. - konfidenciaintervallumok félhossza.

A kiinduló paraméterértékek a következők:

1. táblázat: A számításokhoz használt alapértelmezett paraméterek

\begin{tabular}{|cc|cc|cc|}
\hline$x$ & 40 év & $r$ & $4 \%$ & $\beta_{1}$ & 0,05 \\
\hline$T$ & 10 év & $g$ & $2 \%$ & $\beta_{2}$ & 0,04 \\
\hline$P$ & 100 & $g_{d}$ & $2 \%$ & $\beta_{3}$ & 0,02 \\
\hline$\alpha$ & $85 \%$ & $h$ & $2 \%$ & $\beta_{4}$ & 0,01 \\
\hline$\sigma$ & $20 \%$ & $k$ & $90 \%$ & $\beta_{t}, t \geq 5$ & 0 \\
\hline$\lambda$ & 1 & $k_{d}$ & $90 \%$ & & \\
\hline
\end{tabular}

Forrás: saját számítás 
A fenti paraméterek melletti eredmények:

2. táblázat: Kiinduló paraméterek melletti eredmények GBM modellfeltevés esetén

\begin{tabular}{|c|c|c|c|c|c|}
\hline & $\widehat{V}_{0}$ & $\widehat{\nabla}_{0}^{k v}$ & $V_{0}^{E}$ & $\widehat{o} p_{0}$ & $\%$ \\
\hline & 93,9928 & 94,0052 & 92,1898 & 1,8154 & $1,97 \%$ \\
\hline konf. int. & 0,11965 & 0,01915 & - & 0,01915 & \\
\hline
\end{tabular}

Forrás: saját számitás

Első ránézésre leolvashatjuk, hogy a szerződés értéke törlési opcióval és anélkül is kisebb, mint az induláskor befizetett 100 egységnyi egyszeri dij. Ez reális is amiatt, hogy olyan konstrukcióról van szó, amely a szolgáltatás alapjául csak a díj $\alpha$ százalékát tekinti. A törlési opció értéke kb. 1,8, és ezzel az európai típusú szerződés mintegy 2\%-át teszi ki. Leolvasható az is, hogy a kontrollváltozós becslés jóval pontosabb az alapváltozatnál, tehátérdemes azt használni.

Elsőként megvizsgáltam, mit eredményez a $\lambda$ döntési paraméter változtatása (lásd Melléklet 4. táblázat). Ahogyan azt el is várjuk, $\lambda$ növekedésével csökken az opció értéke, hiszen ez azt jelenti, hogy az ügyfél csak „nagyon előnyös” esetben töröl, vagyis ha a visszavásárlási érték jóval meghaladja a továbbtartásit. $\lambda \geq 1,2$ esetén azt kapjuk, hogy már egyáltalán nem éri meg lejárat előtt törölni: szinte kivétel nélkül a lejárat időpontját kapjuk optimális törlési időpontként, a törlési opció pedig lényegében értéktelen. Kíváncsi voltam arra is, hogy a modell reálisan tudja-e tükrözni azt az esetet, amikor $\lambda<1$, vagyis az illető ügyfél megelégszik egy olyan öszszeggel, amely valamivel kevesebb, mint a tisztán pénzügyi racionalitásból fakadó küszöbérték. Például töröl már akkor, ha a visszavásárlási érték legalább 0,99-szerese a továbbtartásinak. A szimulációk alátámasztották, hogy a várakozásoknak megfelelően ekkor enyhén nő az opció értéke: 1,8215 az induló 1,8154 helyett. Viszont ahogy egyre csökkentjük ezt a döntési paramétert, az opció értéke nemhogy nőne, hanem teljesen elértéktelenedik, hiszen az optimális törlési időpont majdnem minden trajektória mentén eltolódik az első lehetséges időpontra, ami az első évforduló. Itt viszont a büntetőfaktor annyira magas, hogy a szerződés piaci értéke (amit így túlnyomóan az első időponthoz tartozó visszavásárlási érték határoz meg) kisebb lesz, mint a törlési opció nélküli szerződésé. Tehát a büntetőfaktorok változatlansága mellett nem lehet látványosan kimutatni, hogy egyre kisebb $\lambda$ egyre nagyobb opcióértéket eredményezne.

A továbbiakban a különböző garantált kamatlábak változtatásának hatását elemeztem (lásd Melléklet 5. táblázat). Megfigyelhetjük, hogy a szerződés értéke megugrik, amint a garantált kamatlábakat egyszerre megnöveljük, hiszen ekkor törlés esetén biztosan nagyobb kifizetéshez jut az ügyfél, a másik két okból történő megszünés esetén pedig szintén, amennyiben a garancia ITM (in the money) az adott időpontban. A törlési opció viszont már nem ér annyit, mint alapesetben: csak 0,84\%-ot tesz ki a szerződés értékéből. Ez azzal magyarázható, hogy a lejárat, illetve halál esetére garantált $g$ és $g$ kamatlábak növekedése arra sarkallja az ügyfelet, hogy ne mondja fel a szerződését, és ez semlegesíti, sőt visszahúzza azt a hatást, amelyet a törlés esetén garantált $h$ megnövekedett értékétől várnánk. Ha azonban csak a visszavásárlási összegre ható $h$-t növeljük, akkor egyértelműen felértékelődik a törlés lehetősége: az opció értéke több mint duplájára nő.

Megvizsgáltam azt is, hogy mi történik, ha a részvételi szintet vagy a büntetőfaktorokat változtatom (lásd Melléklet 6. táblázat). Látható, hogy a növekvő részvételi szint csökkenti a törlési opció értékét. Ez annak tudható be, hogy ekkor az index hozamának nagyobb része számít bele a lejárati és haláleseti kifizetés meghatározásába, így a becsült továbbtartási érték nagyobb valószínűséggel haladja meg a garantált visszavásárlási értéket, mint alapesetben. Ugyancsak veszít az értékéből a törlési opció, ha nagyobb büntetőfaktorokat alkalmazunk, ami teljesen logikus eredmény. Ha 0,09-nél nagyobb büntetőfaktorokat tekintünk végig a tartam alatt, már szinte semmit nem ér a törlési lehetőség.

Kíváncsi voltam arra is, hogy a szerződés tartamának növelése milyen irányú változást eredményez az opció értékében (lásd Melléklet 7. táblázat). Az intuíció azt sugallja, hogy nőni fog, mivel hoszabb időtávon vizsgálva nagyobb valószínűséggel előfordulhat, hogy adott értékelési időpontban az azonnali visszavásárlási juttatás meg fogja haladni a továbbtartásból származó becsült potenciális nyereséget. Látható, hogy az opciónak a szerződés százalékában kifejezett értéke valóban nő a tartammal, a becslés pontossága azonban egyre romlik.

Eddig láttuk a $\lambda$ szubjektív tényező hatását, majd a szerződésben rögzíthető attribútumokét. Végül azt vizsgáltam, hogyan hat az alaptermékül szolgáló index volatilitásának változtatása, amely egy pénzügyi feltételezés, és külső tényezőnek számít (lásd Melléklet 8. táblázat). Ismeretes, hogy egy opció - mint pénzügyi termék - ára növekszik, ha az alaptermék volatilitása nő. Ez a tény részben esetemben is beigazolódott. Az alacsonyabb, 10\%-os volatilitás mellett a kiindulónál kisebb opcióérték adódott: 1,55. Viszont amikor magasabb, 30\%-os volatilitást tekintettem, akkor sem százalékos arányban, sem nominálisan nem kaptam nagyobb opcióértéket a kiindulónál. A szerződés értéke természetesen nőtt, hiszen az árfolyamok megnövekedett változékonysága miatt potenciálisan sokkal magasabb hozamok adódhatnak lejáratkor, az ugyanebből adódó lefele való elmozdulás ellen pedig a garancia továbbra is véd. Éppen ez lehet az oka annak, hogy nagyon volatilis alaptermék esetén a törlés lehetösége már egyre kevesebbet ér: az ügyfél egyre inkább hajlamos lejáratig tartani a szerződést a nagy hozamok reményében. Ezt a szimuláció is igazolta, hiszen kiragadva az utolsó kísérlet során kapott optimális törlési időpontokat 10, illetve 30\%-os volatilitás esetén, azt tapasztaltam, hogy az utóbbi esetben kb. 700-zal több szcenárió mentén tartotta lejáratig az ügyfél a befektetését.

\section{RSLN modell feltevése melletti eredmények}

Ahhoz, hogy a rezsimváltó lognormális (RSLN) modellkeret feltevése mellett is el tudjam végezni a számításokat, először is konkrét adatokra volt szükség, amelyekből kiindulva a paraméterbecslést elvégezhettem. A szerződés általános jellemzőinek leírásánál példaként felhozott Kronosz nevü VA biztosítás egy euróalapú megtakarítási forma (lásd Termékismertetö, 2017, 5. o.). Ebből kiindulva úgy gondoltam, hogy ha bevezetésre kerülne a magyar 
piacon egy részvényindexhez kötött járadék termék, valószínúleg az is inkább valamely euróban denominált indexet alkalmazná, nem pedig a Budapesti Értéktőzsde indexét, a BUX-ot például. Éppen ezért az Euro Stoxx 50 index historikus adatait tekintettem 1987. január 1. és 2017. március 31. között. Az Euro Stoxx 50 index 12 euróövezeti ország 50 legjelentősebb vállalatának részvényeit foglalja magában. Az adatok feltérképezése érdekében először havi loghozamokat és éves volatilitást számoltam az adatokból, amelyeket a Melléklet 1. ábrája szemléltet. Jól megfigyelhető, hogy vannak kiugró volatilitással rendelkező időszakok, például 1997-1998, a 2000-es évek eleje, majd 2008-2009. Tehát indokolt az RSLN modell feltevése. A paraméterbecslést Excelben végeztem el, és a havi $\operatorname{loghozamok} n=362$ méretü mintája alapján a 3. táblázatban közölt becsült értékeket kaptam.

3. táblázat: A rezsimváltó lognormális modell paramétereinek kalibrálása historikus adatok alapján

\begin{tabular}{|ll|ll|ll|}
\hline$\mu_{1}$ & 0,014 & $\sigma_{1}$ & 0,0345 & $p_{1,2}$ & 0,0635 \\
\hline$\mu_{2}$ & $-0,019$ & $\sigma_{2}$ & 0,0771 & $p_{2,1}$ & 0,1465 \\
\hline
\end{tabular}

Forrás: saját számitás

A modell illeszkedését meg is vizsgáltam a reziduumok normalitásának tesztelésével. A kapott reziduálisok Q-Q-plotja, valamint a Shapiro-Wilk teszt magas p-értéke $(0,575)$ alapján elfogadható a normalitás feltevés, ezáltal pedig a modell jó illeszkedése.

Ahhoz, hogy az RSLN modell keretén belül is éves gyakorisággal tudjuk az index alakulásának trajektóriáit generálni, a havi adatok alapján becsült átmenetmátrixot hatványozással évessé alakítjuk : $P_{\text {éves }}=P^{12}$. Az így kapott éves átmenetvalószínűségek: $p_{12 e ́ v e s}=0,2846, p_{21, e ́ v e s}=0,6564$. Az éves átmenetmátrixot használtam az 1-es állapotban töltött időszakok számát jelölő C eloszlásának meghatározásához is. A becsült havi volatilitások $\sigma_{1}=11,98 \%$, illetve $\sigma_{2}=26,72 \%$ éves értékeknek felelnek meg. Ezekből indultam ki az RSLN modell szerinti szimulációk során. Hardy (2001) megjegyzi, hogy ha át akarunk térni egy kockázatsemleges $Q$ mértékre úgy, hogy amellett is ugyanaz az átmenetmátrix legyen érvényes, amelyet a historikus adatok alapján becsültünk, akkor az eredeti $\mu_{-} 1$ és $\mu_{2}$ várható érték paraméterek helyett, amelyek az állapotokat jellemzik, $\mu_{1}^{\prime}=\mathrm{r}-\sigma_{1}^{2} / 2$, illetve $\mu_{2}^{\prime}=r-\sigma_{2}^{2} / 2$ használandó, ahol $r$ a kockázatmentes kamatláb. Az $S_{t}$ árfolyamat realizációinak szimulálásához épp erre volt szükség, amelyet Hardy (2003) 98. oldalán található algoritmus szerint végeztem el.

A 9. táblázatban (lásd Melléklet) összefoglalt eredményekből az derül ki, hogy enyhén alacsonyabb értékek adódtak, mint a GBM modellfeltevéssel, azonban egymáshoz viszonyítva ugyanazt a mintázatot mutatják a paraméterek módosításával kapott eredmények.

Két vizsgált paraméter - a tartam és a garantált lejárati és haláleseti kamatlábak hatását ábrán is szemléltetem (lásd Melléklet 2. ábra, 3. ábra). Az opcióérték az európai típusú szerződés értékének százalékában van kifejezve.

\section{Összefoglalás}

Dolgozatomban bemutattam a legkisebb négyzetes Monte-Carlo (LSMC) szimulációs technika alkalmazhatóságát életbiztosítási szerződésekbe épített törlési opciók értékelésére. A módszer megvalósításának szemléltetése céljából egy részvényindexhez kötött járadékterméket tekintettem. A módszer leglényegesebb lépése a szerződés továbbtartási értékének mint feltételes várható értéknek a megbecslése minden évfordulón, és ennek segítségével az optimális törlési időpont meghatározása a részvényindex alakulásának minden realizációja mentén.

A kérdéses alaptermék dinamikáját kétféleképpen modelleztem: egyszerű geometriai Brown-mozgással és rezsimváltó lognormális modell segítségével. Utóbbi paramétereit az Euro Stoxx 50 index historikus adataiból becsültem. Az előbbi két modell alapján előállított végeredmények: a törlési opciót nem tartalmazó, ,,európai típusú” szerződés kezdeti igazságos értéke, a törlési opcióval rendelkező, ,,amerikai típusú" szerződés kezdeti igazságos ér tékének becslése, valamint a törlési opció értékének becslése. A becslések pontosságát egy kontrollváltozó bevezetésével jelentősen tudtam növelni. A különböző modellfeltevések mellett nagyon hasonló eredmények adódtak, a GBM modell általában enyhén magasabb értékekhez vezetett.

A kulcskérdésre, hogy mennyit tesz hozzá a szerződés értékéhez a lejárat előtti visszavásárlás lehetősége, azt a választ kaptam, hogy az alapértelmezett paraméterek mellett a szerződésértéknek körülbelül 2\%-át teszi ki a törlési opció. Ez a számszerüsített mérték is rávilágít arra, hogy igencsak fontos a különböző, szerződésbe épített opciókat és garanciákat kellő elővigyázatossággal kezelni, értéküket minél pontosabban meghatározni és figyelembe venni. A használt módszer gyorsasága lehetővé tette a lényeges paraméterek - mint például a garantált minimum kamatlábak, büntetőfaktorok stb. - hatásának vizsgálatát is. Ez az előny is alátámasztja a módszer gyakorlati jelentőségét. Ugyanakkor a bemutatott eredmények alapján elmondhatjuk, hogy az elvégzett szimulációs kísérletek minden esetben a józan észt igazolták.

Az LSMC technika tehát biztosítási területen is sikerrel alkalmazható. Egy tényleges gyakorlati felhasználás érdekében a dolgozatban bemutatott modellt nyilván finomítani kellene. A továbbfejlesztési lehetőségek között említhető például realisztikusabb modellek használata az alaptermék dinamikájának leírására, vagy a konstans kockázatmentes kamatláb helyett valamely sztochasztikus kamatlábmodell bevezetése. Ugyanakkor be lehetne építeni a pusztán pénzügyi racionalitáson alapuló ügyfélviselkedés helyett valamely más - például egészségi állapottól függő - optimális döntési mechanizmust. 


\section{MELLÉKLETEK}

4. táblázat: Változó $\lambda$ melletti eredmények GBM modellfeltevés esetén

\begin{tabular}{|c|c|c|c|c|c|}
\hline \multicolumn{2}{|c|}{$\lambda=1,05$} & \multicolumn{5}{|c|}{} \\
\cline { 1 - 2 } & $\widehat{V}_{0}$ & $\widehat{V}_{0}^{k v}$ & $V_{0}^{E}$ & $\widehat{O} p_{0}$ & $\%$ \\
\hline & 93,0668 & 93,0797 & 92,1898 & 0,8899 & $0,97 \%$ \\
\hline konf. int. & 0,11183 & 0,03315 & - & 0,03315 & \\
\cline { 1 - 2 } & & \multicolumn{3}{|c}{}
\end{tabular}

\begin{tabular}{|c|c|c|c|c|c|}
\hline \multicolumn{2}{|c|}{$\lambda=1,2$} & \multicolumn{5}{c|}{} \\
\hline & $\hat{V}_{0}$ & $\hat{V}_{0}^{k v}$ & $V_{0}^{E}$ & $\hat{O} p_{0}$ & $\%$ \\
\hline & 92,1771 & 92,1905 & 92,1898 & 0,0007 & $0,0008 \%$ \\
\hline konf. int. & 0,12112 & 0,00883 & - & 0,00883 & \\
\cline { 1 - 2 } & & \multicolumn{4}{|c}{}
\end{tabular}

\begin{tabular}{|c|c|c|c|c|c|}
\hline \multicolumn{2}{|c|}{$\lambda=0,99$} & \multicolumn{5}{c|}{} \\
\cline { 1 - 2 } & $\widehat{V}_{0}$ & $\widehat{V}_{0}^{k v}$ & $V_{0}^{E}$ & $\widehat{O} p_{0}$ & $\%$ \\
\hline & 93,9992 & 94,0113 & 92,1898 & 1,8215 & $1,98 \%$ \\
\hline konf. int. & 0,12344 & 0,02374 & - & 0,02374 & \multicolumn{1}{c}{} \\
\cline { 1 - 2 } & & & &
\end{tabular}

Forrás: saját számitás

5. táblázat: Változó $g, g_{d}$ és h melletti eredmények GBM modellfeltevés esetén

\begin{tabular}{|c|c|c|c|c|c|}
\hline \multicolumn{5}{|c|}{$g=g_{d}=h=0,03$} & \multicolumn{5}{l|}{} \\
\hline & $\widehat{V}_{0}$ & $\widehat{V}_{0}^{k v}$ & $V_{0}^{E}$ & $\widehat{O} p_{0}$ & $\%$ \\
\hline & 96,9705 & 96,9837 & 96,1712 & 0,8125 & $0,84 \%$ \\
\hline konf. int. & 0,11552 & 0,01656 & - & 0,01656 & \\
\cline { 1 - 4 } & & & \multicolumn{4}{|c}{}
\end{tabular}

\begin{tabular}{|c|c|c|c|c|c|}
\hline \multicolumn{2}{|c|}{$h=0,03$} & \multicolumn{1}{c|}{} \\
\hline & $\hat{V}_{0}$ & $\hat{V}_{0}^{k v}$ & $V_{0}^{E}$ & $\hat{O} p_{0}$ & $\%$ \\
\hline & 96,5127 & 96,5247 & 92,1898 & 4,3349 & $4,7 \%$ \\
\hline konf. int. & 0,11969 & 0,02337 & - & 0,02337 & \\
\cline { 1 - 2 } & &
\end{tabular}

Forrás: saját számitás
6. táblázat: Változó $k$, $k$ és $\beta$ melletti eredmények GBM modellfeltevés esetén

\begin{tabular}{|c|c|c|c|c|c|}
\hline \multicolumn{2}{|c|}{$k=k_{d}=1$} & \multicolumn{5}{c|}{} \\
\cline { 1 - 2 } & $\widehat{V}_{0}$ & $\widehat{V}_{0}^{k v}$ & $V_{0}^{E}$ & $\widehat{O} p_{0}$ & $\%$ \\
\hline & 98,8885 & 98,9016 & 97,3499 & 1,5517 & $1,59 \%$ \\
\hline konf. int. & 0,14972 & 0,01815 & - & 0,01815 & \multicolumn{3}{|c}{} \\
\cline { 1 - 2 } & & &
\end{tabular}

\begin{tabular}{|c|c|c|c|c|c|}
\hline \multirow{2}{*}{\multicolumn{2}{|c|}{\begin{tabular}{|l}
$\beta_{1}=0,2, \beta_{2}=0,15$, \\
$\beta_{4}=0,05, \beta_{t}=0, t \geq$ \\
\end{tabular}}} & & & & \\
\hline & & $\widehat{V}_{0}^{k v}$ & $V_{0}^{E}$ & $\hat{o} p_{0}$ & $\%$ \\
\hline & 93,8586 & 93,8711 & 92,1898 & 1,6813 & $1,82 \%$ \\
\hline konf. int. & 0,11642 & 0,01873 & - & 0,01873 & \\
\hline
\end{tabular}

\begin{tabular}{|c|c|c|c|c|c|}
\hline \multicolumn{2}{|c|}{$\beta_{t}=0,09, t \geq 1$} & & & & \\
\hline & $\hat{V}_{0}$ & $\widehat{V}_{0}^{k v}$ & $V_{0}^{E}$ & $\hat{o} p_{0}$ & $\%$ \\
\hline & 92,2306 & 92,2438 & 92,1898 & 0,054 & $0,06 \%$ \\
\hline konf. int. & 0,12291 & 0,01447 & - & 0,01447 & \\
\hline
\end{tabular}

Forrás: saját számités

7. táblázat: Növekvö tartam melletti eredmények GBM modellfeltevés esetén

\begin{tabular}{|c|c|c|c|c|c|}
\hline \multicolumn{2}{|c|}{$T=15$} & \multicolumn{1}{c|}{} \\
\hline & $\hat{V}_{0}$ & $\hat{V}_{0}^{k v}$ & $V_{0}^{E}$ & $\hat{O} p_{0}$ & $\%$ \\
\hline & 93,4209 & 93,4536 & 90,5699 & 2,8836 & $3,18 \%$ \\
\hline konf. int. & 0,14825 & 0,05628 & - & 0,05628 & \multicolumn{4}{c}{} \\
\cline { 1 - 3 } & &
\end{tabular}

\begin{tabular}{|c|c|c|c|c|c|}
\hline \multicolumn{2}{|c|}{$T=18$} & & & & \\
\hline & $\widehat{V}_{0}$ & $\widehat{V}_{0}^{k v}$ & $V_{0}^{E}$ & $\hat{O} p_{0} \%$ & \\
\hline & 92,2005 & 92,2742 & 89,3707 & 2,9036 & $3,25 \%$ \\
\hline konf. int. & 0,17563 & 0,09012 & - & 0,09012 & \\
\hline
\end{tabular}

Forrás: saját számitás 
8. táblázat: Változó volatilitás melletti eredmények GBM modellfeltevés esetén

\begin{tabular}{|c|c|c|c|c|c|}
\hline \multicolumn{2}{|c|}{$\sigma=10 \%$} & \multirow[b]{2}{*}{$\widehat{V}_{0}^{k v}$} & \multirow[b]{2}{*}{$V_{0}^{E}$} & \multirow[b]{2}{*}{$\hat{o} p_{0}$} & \multirow[b]{2}{*}{$\%$} \\
\hline & $\widehat{V}_{0}$ & & & & \\
\hline & 86,7919 & 86,7987 & 85,2478 & 1,5509 & $1,82 \%$ \\
\hline konf. int. & 0,04888 & 0,01651 & - & 0,01651 & \\
\hline \multicolumn{2}{|c|}{$\sigma=30 \%$} & & & & \\
\hline & $\hat{V}_{0}$ & $\widehat{V}_{0}^{k v}$ & $V_{0}^{E}$ & $\hat{O} p_{0}$ & $\%$ \\
\hline & 99,5145 & 99,537 & 98,6747 & 0,8624 & $0,87 \%$ \\
\hline konf. int. & 0,19403 & 0,08411 & - & 0,08411 & \\
\hline
\end{tabular}

Forrás: saját számitás

9. táblázat: Az RSLN modellfeltevéssel kapott eredmények különböző paraméterbeállitások mellett

\begin{tabular}{|c|c|c|c|c|c|}
\hline \multicolumn{2}{|c|}{ kiinduló paraméterek } & & & & \\
\hline & $\hat{V}_{0}$ & $\widehat{V}_{0}^{k v}$ & $V_{0}^{E}$ & $\hat{O} p_{0}$ & $\%$ \\
\hline & 92,1941 & 92,2484 & 90,5192 & 1,7292 & $1,91 \%$ \\
\hline konf. int. & 0,15332 & 0,02721 & - & 0,02721 & \\
\hline
\end{tabular}

\begin{tabular}{|c|c|c|c|c|c|}
\hline \multicolumn{2}{|c|}{$\lambda=1,05$} & \multicolumn{5}{|c|}{} \\
\cline { 1 - 2 } & $\hat{V}_{0}$ & $\hat{V}_{0}^{k v}$ & $V_{0}^{E}$ & $\widehat{O} p_{0}$ & $\%$ \\
\hline & 91,3563 & 91,4132 & 90,5192 & 0,894 & $0,99 \%$ \\
\hline konf. int. & 0,17105 & 0,02964 & - & 0,02964 & \\
\cline { 1 - 2 } & & &
\end{tabular}

\begin{tabular}{|c|c|c|c|c|c|}
\hline \multicolumn{2}{|c|}{$\lambda=1,15$} & \multicolumn{5}{c|}{} \\
\cline { 1 - 2 } & $\widehat{V}_{0}$ & $\widehat{V}_{0}^{k v}$ & $V_{0}^{E}$ & $\hat{O} p_{0}$ & $\%$ \\
\hline & 90,4869 & 90,5448 & 90,5192 & 0,0256 & $0,03 \%$ \\
\hline konf. int. & 0,16888 & 0,02921 & - & 0,02921 & \\
\cline { 1 - 2 } & & &
\end{tabular}

\begin{tabular}{|c|c|c|c|c|c|}
\hline \multicolumn{6}{|c|}{$g=g_{d}=h=0,03$} \\
\hline & $\widehat{V}_{0}$ & $\widehat{V}_{0}^{k v}$ & $V_{0}^{E}$ & $\widehat{O} p_{0}$ & $\%$ \\
\hline & 95,0228 & 95,074 & 94,3032 & 0,7708 & $0,82 \%$ \\
\hline konf. int. & 0,14876 & 0,02408 & - & 0,02408 & \\
\hline \multicolumn{6}{|c|}{$h=0,03$} \\
\hline & $\widehat{V}_{0}$ & $\widehat{V}_{0}^{k v}$ & $V_{0}^{E}$ & $\widehat{O} p_{0}$ & $\%$ \\
\hline & 94,5966 & 94,6488 & 90,5192 & 4,1296 & $4,56 \%$ \\
\hline konf. int. & 0,14931 & 0,02386 & - & 0,02386 & \\
\hline
\end{tabular}

\begin{tabular}{|c|c|c|c|c|c|}
\hline \multicolumn{2}{|c|}{$k=k_{d}=1$} & \multicolumn{5}{c|}{} \\
\cline { 1 - 2 } & $\widehat{V}_{0}$ & $\widehat{V}_{0}^{k v}$ & $V_{0}^{E}$ & $\hat{O} p_{0}$ & $\%$ \\
\hline & 96,6578 & 96,7259 & 95,2632 & 1,4627 & $1,54 \%$ \\
\hline konf. int. & 0,19206 & 0,02336 & - & 0,02336 & \\
\cline { 1 - 2 } & & \multicolumn{3}{|c}{}
\end{tabular}

\begin{tabular}{|c|c|c|c|c|c|}
\hline \multicolumn{2}{|c|}{$\begin{aligned} \beta_{1}=0,2, \beta_{2} & =0,15 \\
\beta_{4}=0,05, \beta_{t} & =0, t \geq\end{aligned}$} & & & & \\
\hline & $\widehat{V}_{0}$ & $\widehat{V}_{0}^{k v}$ & $V_{0}^{E}$ & $\hat{o} p_{0}$ & $\%$ \\
\hline & 92,0486 & 92,1037 & 90,5192 & 1,5845 & $1,75 \%$ \\
\hline konf. int. & 0,15591 & 0,02453 & - & 0,02453 & \\
\hline
\end{tabular}

\begin{tabular}{|c|c|c|c|c|c|}
\hline \multicolumn{2}{|c|}{$T=15$} & \multicolumn{5}{c|}{} \\
\hline & $\widehat{V}_{0}$ & $\widehat{V}_{0}^{k v}$ & $V_{0}^{E}$ & $\hat{O} p_{0}$ & $\%$ \\
\hline & 91,8341 & 91,7954 & 88,8631 & 2,9323 & $3,3 \%$ \\
\hline konf. int. & 0,18672 & 0,04723 & - & 0,04723 & \multicolumn{3}{|c}{} \\
\cline { 1 - 2 } & &
\end{tabular}

Forrás: saját számitás

1. ábra: Az Euro Stoxx 50 index havi loghozamának és éves volatilitásának alakulása 1987-2017 között

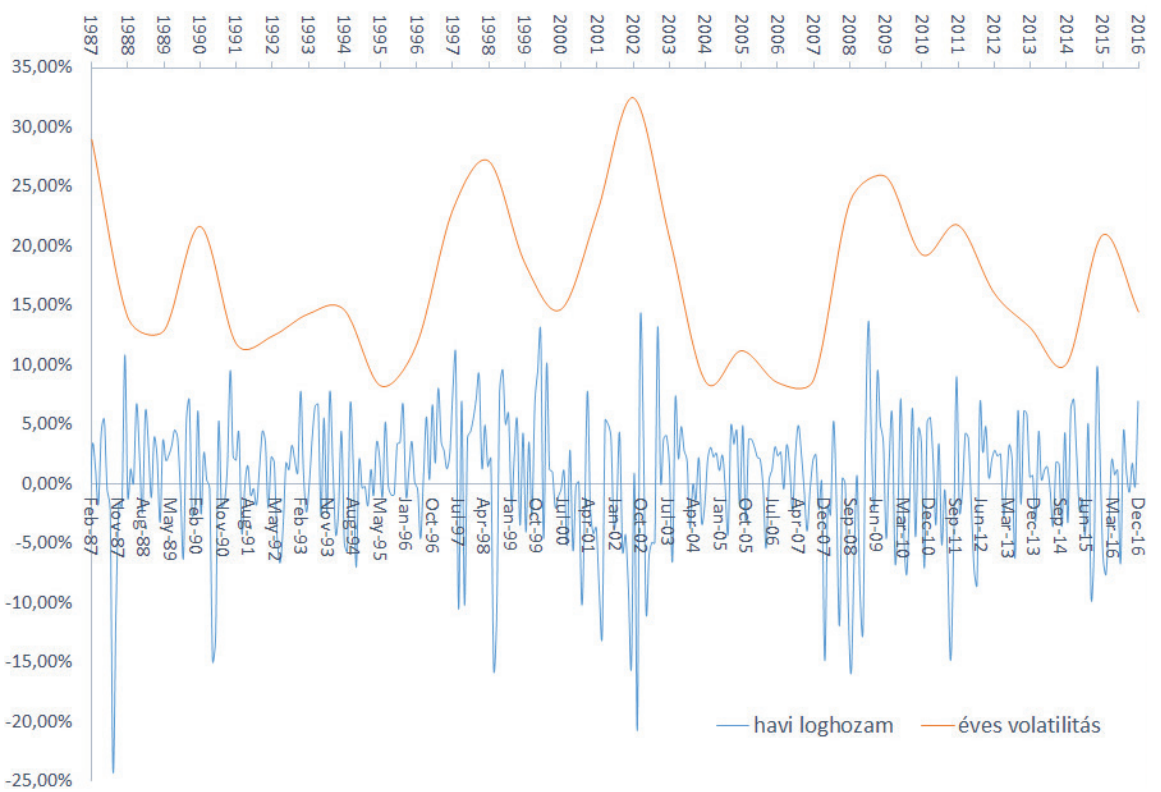

Forrás: saját szerkesztés 


\section{2. ábra: Az opció értékének alakulása a tartam függvényében}

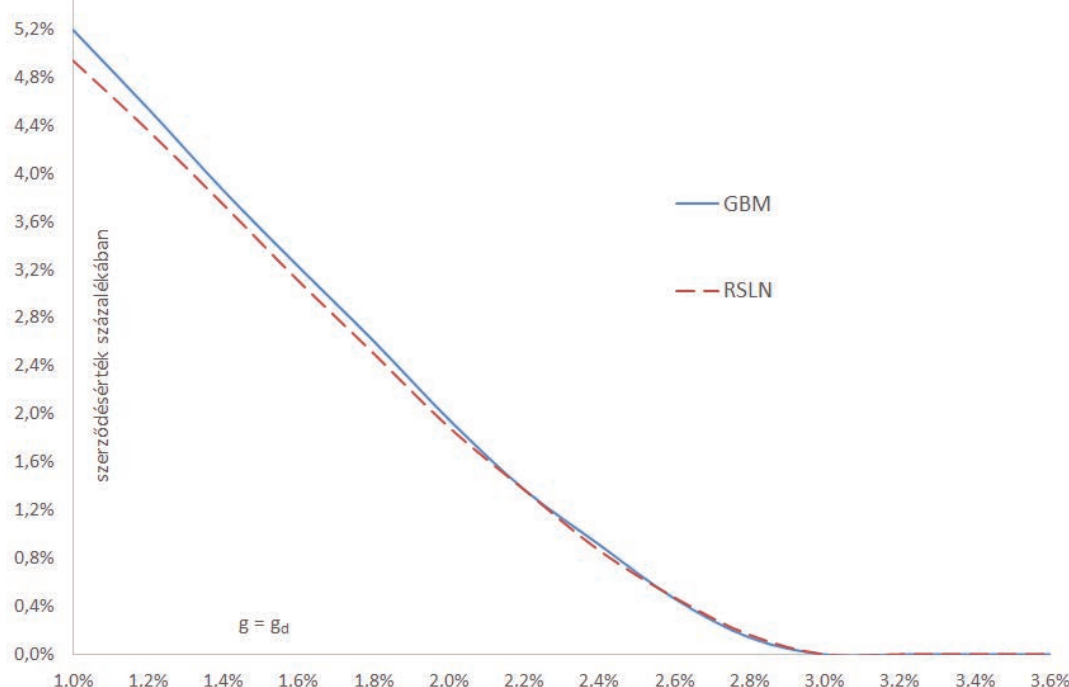

Forrás: saját szerkesztés

3. ábra: Az opció értékének alakulása a garantált kamatlábak függvényében

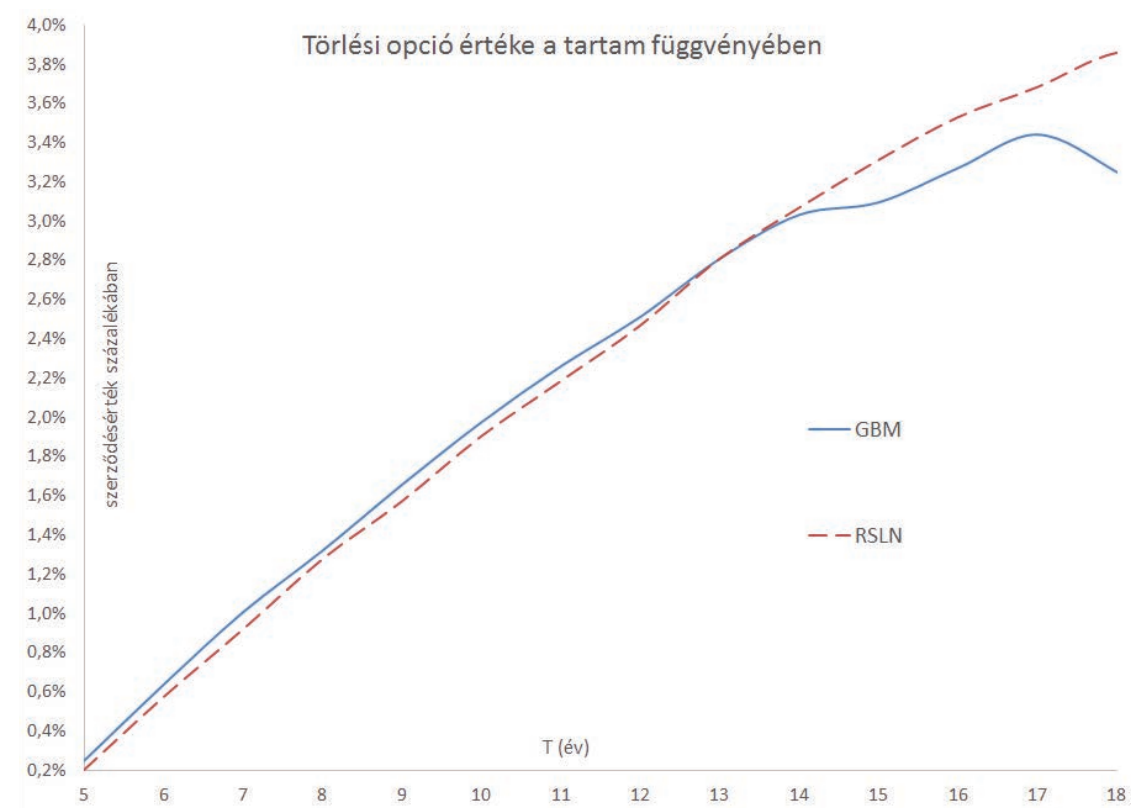

Forrás: saját szerkesztés

\section{HIVATKOZÁSOK}

A termékismertetőben leírt specifikáció (lásd (Termékismertető, 2017)) egy ún. variable annuity (VA) terméket határoz meg, amely viszont nem azonos az equity-indexed annuity fogalmával. Az egyik leg fontosabb különbség talán a flexibilitás. VA termék esetén lehetőség van választani és később váltogatni az eszközalapok között, amelybe a befizetések befektetésre kerülnek, míg általában a választott alapok teljes hozamát jóváírják a szerződő befizetésein.

$\pi_{1} \mathrm{p}_{1,1}+\pi_{2} \mathrm{p}_{2,1}=\pi_{1}$ es $\pi_{1} \mathrm{p}_{1,2}+\pi_{2} \mathrm{p}_{2,2}=\pi_{2}$

"http://db.komal.hu/KomalHU/cikk.phtml?id=199639

\%

"Ez migno

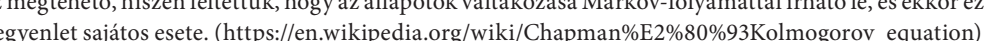

\section{IRODALOMJEGYZÉK}

Andreatta, G. \& Corradin, S. (2003): Fair value of life liabilities with embedded options: an application to a portfolio of Italian insurance policies, RAS Spa, Planificarione Redditivita di Gruppo

ndreatta_Corradin.pdf

Bernard, C. \& Lemieux, C. (2008): Fast simulation of equity-linked life insurance contracts with a surrender option, Department of Statistics and Actuarial Science, University of Waterloo

Online: http://www.informs-sim.org wsospapers/052.p

[utoljára ellenőrizve: 2017. 08. 04,

hing model oflong-term stock returns, North American Actuarial Journal, Volume 5, Issue 2, pp. 41-53. Hardy, M. (2003): Investment Guarantees. Modeling and Risk Management for Equity-Linked Life Insurance, John Wiley \& Sons, Inc. Journal of Risk and Insurance, Volume 7, Issue 2, pp. 105-142.

Longstaff, F. A. \& Schwartz, E. F. (2001): Valuing American Options by Simulation: A Simple Least-Squares Approach, The Review of Financial Studies, Volume 14, Issue 1, pp. 113-147.

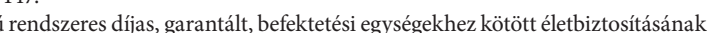

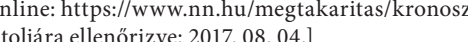

